Article

\title{
Field Calibrations of Soil Moisture Sensors in a Forested Watershed
}

\section{Farhat Abbas, Ali Fares * and Samira Fares}

Natural Resources and Environmental Management Department, University of Hawaii-Manoa, Honolulu, HI 96822, USA; E-Mails: farhat@ hawaii.edu (F.A.); sfares@ hawaii.edu (S.F.)

* Author to whom correspondence should be addressed; E-Mail: afares@ hawaii.edu; Tel.: +1-808-956-6361; Fax: +1-808-956-6539.

Received: 28 April 2011 / in revised form: 20 May 2011 / Accepted: 7 June 2011 Published: 16 June 2011

\begin{abstract}
Spatially variable soil properties influence the performance of soil water content monitoring sensors. The objectives of this research were to: (i) study the spatial variability of bulk density $\left(\rho_{\mathrm{b}}\right)$, total porosity $\left(\theta_{\mathrm{t}}\right)$, clay content $(\mathrm{CC})$, electrical conductivity (EC), and $\mathrm{pH}$ in the upper Mākaha Valley watershed soils; (ii) explore the effect of variations in $\rho_{\mathrm{b}}$ and $\theta_{\mathrm{t}}$ on soil water content dynamics, and (iii) establish field calibration equations for EC-20 (Decagon Devices, Inc), ML2x (Delta-T-Devices), and SM200 (Delta-T-Devices) sensors to mitigate the effect of soil spatial variability on their performance. The studied soil properties except $\mathrm{pH}$ varied significantly $(P<0.05)$ across the soil water content monitoring depths $(20$ and $80 \mathrm{~cm}$ ) and six locations. There was a linear positive and a linear inverse correlation between the soil water content at sampling and $\rho_{\mathrm{b}}$, and between the soil water content at sampling and $\theta_{\mathrm{t}}$, respectively. Values of laboratory measured actual $\theta_{\mathrm{t}}$ correlated $(r=0.75)$ with those estimated from the relationship $\theta_{\mathrm{t}}=1-\rho_{\mathrm{b}} / \rho_{\mathrm{s}}$, where $\rho_{\mathrm{s}}$ is the particle density. Variations in the studied soil properties affected the performance of the default equations of the three tested sensors; they showed substantial under-estimations of the actual water content. The individual and the watershed-scale field calibrations were more accurate than their corresponding default calibrations. In conclusion, the sensors used in this study need site-specific calibrations in order to mitigate the effects of varying properties of the highly weathered tropical soils.
\end{abstract}

Keywords: variable soil properties; soil water content; sensor field calibration; tropical soils 


\section{Introduction}

Non-agricultural forested lands exhibit spatially variable soil water content as a function of soil basic properties [1], land cover [2], and topography [3]. Soil water content varies across a soil profile due to changes in $\rho_{\mathrm{b}}, \theta_{\mathrm{t}}$, and CC [4,5]. Surface soil layers of forested watersheds are subject to higher soil water content dynamics due to evapotranspiration and rainfall; deep soil profiles have higher water content due to uniform conditions.

Accurate measurement of soil water content is important for water balance and hydrologic flux calculations, rainfall-runoff-infiltration models, ground truthing of remote sensing data, irrigation scheduling, water allocation calculations, and evaluation of potential drought impacts on stream flow [6]. Reliable measurement of soil water content with water sensors has been challenging in forested lands due to spatially variable soil physical and hydrological properties [6]. Variations in $\rho_{\mathrm{b}}$ have greater effects on sensor readings than those caused by CC or organic matter content [7].

Direct measurements of soil water content by the thermo-gravimetric method is more accurate than any other indirect method; however, this method is labor intensive, time consuming, destructive, and discrete for repetitive measurements. Indirect techniques of soil water content measurement (e.g., single- and multi-capacitance soil water content monitoring systems) overcome these disadvantages of the thermo-gravimetric method; in addition, they enable automate real-time spatially-distributed data collection [8,9]. Such techniques have been used for real-time monitoring of soil water content at different scales, i.e., greenhouse, field plots, watersheds subject to different agricultural management practices. Installation of theses sensors begins with a careful selection of monitoring locations, which are conceptually subdivided into macro- and micro-zones [8]. Macro-zone refers to the selection of one or several locations in a watershed or in an agricultural field characterized by dominant topography, soil type, vegetation, and management practices. On the other hand, micro-zone selection aims at determining the position of the sensor in relation to individual points/locations, soil depths (shallow vs. deep) or irrigation delivery points (drip or sprinkler emitter).

The single soil water content monitoring sensors EC-20 [10], ML2x [11], and SM200 [11] have been used in agricultural and non-agricultural settings. These sensors were calibrated under different soil and environmental conditions [12,13]. Czarnomski et al. [14] compared the accuracy and precision of the EC-20 with those of a TDR under field and laboratory conditions. They found that the default calibration equation of EC-20 underestimated water content by up to $0.12 \mathrm{~cm}^{3} \mathrm{~cm}^{-3}$ and that EC-20 wasn't sensitive to $\rho_{\mathrm{b}}$; they also concluded that the EC-20 data were more consistent than those of TDR. Logsdon and Hornbuckle [15] reported that the larger measurement volume of the CS616 resulted in less spatial variability of soil water content compared to that of the ML2x because of the relatively smaller measurement volume of the latter. The use of default calibration equations results in considerable over- and under-estimations of soil water content measured by the EC-20 and ML2x, respectively [12]. These findings strongly recommend site-specific calibrations to improve the accuracy and performance of soil water content monitoring devices. Hu et al. [16] calibrated CS616, ML2x, and SM200 units and reported that the ML2x performed better than the other two sensors with new calibration equations.

The Mākaha Valley watershed is located in the dry leeward side of the island of O'ahu, HI, USA (Figure 1). This watershed has been the home of a long-term hydrologic study aiming at determining the 
effects of rainfall variability, groundwater pumping, and invasive species on its hydrology and water quality [17]. The watershed has been instrumented with EC-20, ML2x, and SM200 sensors, and other equipment for real-time monitoring of water budget components. The objectives of this study were to (i) study the spatial variability of $\rho_{\mathrm{b}}, \theta_{\mathrm{t}}, \mathrm{CC}, \mathrm{EC}$, and $\mathrm{pH}$ of the upper Mākaha Valley watershed soil, (ii) explore the effect of variations in $\rho_{\mathrm{b}}$ and $\theta_{\mathrm{t}}$ on soil water content dynamics, and (iii) establish field calibration equations for EC-20, ML2x, and SM200 sensors to improve their performance.

Figure 1. A map showing the upper Mākaha Valley sub-watershed and the six monitoring locations of the field calibration from which soil samples were collected and used to determine bulk density, total porosity, clay content, electrical conductivity and $\mathrm{pH}$.

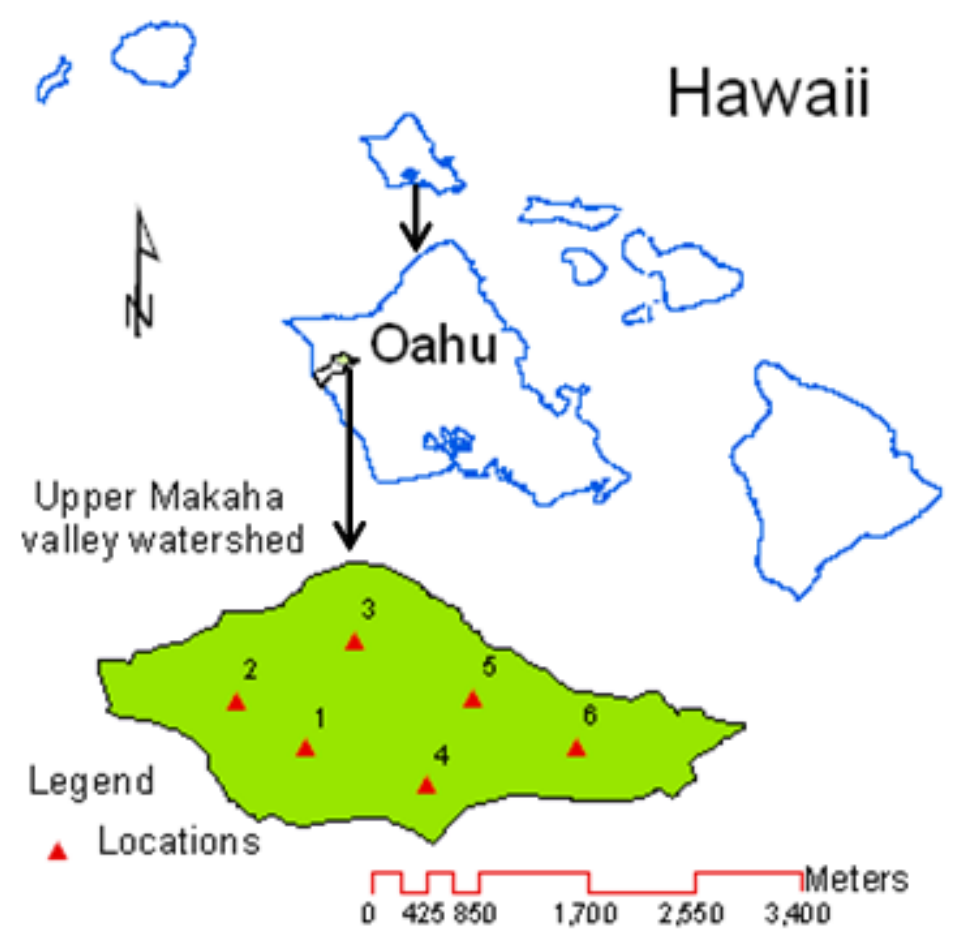

\section{Materials and Methods}

\subsection{Soil Water Content Sensing Devices}

The sensors calibrated during this study were the EC-20, ML2x, and SM200 (Table 1). The calibration equation of the EC-20 is a linear function that relates EC-20 readings (V) to the actual soil water content. There is a linear correlation between soil water content measured with the ML2x and the square root of the dielectric constant $(\sqrt{\varepsilon})[18,19]$. The SM200 probe has a similar calibration equation as that of the ML2x.

Table 1. Sensors used in this study, their operating frequency, and default calibration equations.

\begin{tabular}{lll}
\hline Sensors & Operating frequency, MHz & Default Calibration Equation \\
\hline EC-20 & 5 & $y=0.695 x-0.29$ \\
ML2x & 100 & $y=0.560 x^{3}-0.762 x^{2}+0.762 x-0.063$ \\
SM200 & 100 & $y=1.611 x^{5}-5.48 x^{4}+7.248 x^{3}-4.61 x^{2}+1.917 x-0.071$ \\
\hline
\end{tabular}

$y$ : actual volumetric soil water content $\left(\mathrm{cm}^{3} \mathrm{~cm}^{-3}\right) ; x$ : sensor readings $(\mathrm{V})$. 


\subsection{Experimental Locations}

Field calibrations of the selected sensors were performed at two depths of six monitoring locations across the upper Mākaha Valley sub-watershed (Figure 1). These locations, referred to as locations 1 through 6 from here onward, were initially selected to represent the spatial variations of the topography, soil, and vegetation covers across the study area (Table 2). Soils in the lower valley are less permeable than those along the valley ridges. The soils over the valley floor and along the southeastern ridge of the upper valley are mainly clay loam, silty loam, and silty clay [20].

Table 2. The elevation, saturated hydraulic conductivity $\left(K_{\mathrm{sat}}\right)$, the NRCS soil series, particle size distribution, and the USDA soil classification of the soil samples collected from 20 and $80 \mathrm{~cm}$ depths at the six monitoring locations in the upper Mākaha Valley sub-watershed.

\begin{tabular}{|c|c|c|c|c|c|c|c|}
\hline Location & $\begin{array}{c}\text { Elevation, } \\
\text { m }\end{array}$ & $\begin{array}{c}K_{\text {sat }}, \\
\mathrm{cm} \mathrm{h}^{-1}\end{array}$ & $\begin{array}{l}\text { Depth, } \\
\text { cm }\end{array}$ & $\begin{array}{c}\text { NRCS Soil } \\
\text { Series }\end{array}$ & $\begin{array}{r}\text { Clay } \\
\mathrm{g}\end{array}$ & Sand & $\begin{array}{c}\text { USDA } \\
\text { Soil texture }\end{array}$ \\
\hline \multirow{2}{*}{1} & \multirow{2}{*}{343} & \multirow{2}{*}{90.2} & 20 & Mollisol & 313 & 269 & Clay loam \\
\hline & & & 80 & Mollisol & 313 & 269 & Clay loam \\
\hline \multirow{2}{*}{2} & \multirow{2}{*}{477} & \multirow{2}{*}{10.8} & 20 & Inceptisol & 610 & 308 & Clay \\
\hline & & & 80 & Inceptisol & 690 & 250 & Clay \\
\hline \multirow{2}{*}{3} & \multirow{2}{*}{538} & \multirow{2}{*}{31.4} & 20 & Ultisol & 521 & 167 & Clay \\
\hline & & & 80 & Ultisol & 640 & 250 & Clay \\
\hline \multirow{2}{*}{4} & \multirow{2}{*}{601} & \multirow{2}{*}{63.8} & 20 & Ultisol & 313 & 218 & Clay loam \\
\hline & & & 80 & Ultisol & 288 & 320 & Clay loam \\
\hline \multirow{2}{*}{5} & \multirow{2}{*}{609} & \multirow{2}{*}{16.5} & 20 & Ultisol & 263 & 421 & Loam \\
\hline & & & 80 & Ultisol & 288 & 661 & Sandy loam \\
\hline \multirow{2}{*}{6} & \multirow{2}{*}{725} & \multirow{2}{*}{19.3} & 20 & Andisol & 157 & 371 & Loam \\
\hline & & & 80 & Andisol & 230 & 218 & Silt loam \\
\hline
\end{tabular}

\subsection{Soil Properties}

Disturbed and undisturbed soil core samples were collected in three replicates from each depth of the six locations. The undisturbed soil core samples (radius $=2.5 \mathrm{~cm}$; height $=7.5 \mathrm{~cm}$ ) were collected with a sludge hammer soil sampler (Soilmoisture Equipment Crop. Santa Barbara, CA, USA). The trimmed soil cores were sealed with plastic caps, placed in labeled zip-lock plastic bags, and taken to the laboratory to measure their $\rho_{\mathrm{b}}$ and $\theta_{\mathrm{t}}$ following the standard procedures described by Grossman and Reinsch [21] and Flint and Flint [22], respectively.

Replicates of the disturbed bulk soil samples were thoroughly mixed to produce a representative sample for each depth and location. These samples were air dried and sieved $(<2 \mathrm{~mm})$; a sub-sample was used to determine particle size distribution using the hydrometer method [23]. The textural triangle of the United States Department of Agriculture (USDA) classification scheme was used to determine the soil particle size distributions. Color schemes were used to determine the NRCS (Natural Resources Conservation Services) soil series information. EC and pH of these samples were 
measured from their 1:2 soil:water solutions with a multi-functional sympHony ${ }^{\circledR}$ meter (Model SB90M5; Batavia, IL, USA) and the respective electrodes.

\subsection{Calibration Procedure}

Two units of each EC-20, ML2x, and SM200 sensor were installed at 20 and $80 \mathrm{~cm}$ depths at locations 1 through 6 following standard procedures [8]. Various soil water content levels ranging between field capacity $\left(\sim 0.23 \mathrm{~cm}^{3} \mathrm{~cm}^{-3}\right)$ and saturation $\left(\sim 0.59 \mathrm{~cm}^{3} \mathrm{~cm}^{-3}\right)$ were generated by intermittently applying water at and surrounding the sensor installation points. Watermark soil matric potential sensors were used to monitor the soil water potential at various soil water content levels. The soil water sensors and matric potential sensors were logged with their corresponding data loggers at 1-min intervals. At least 3 uniform sensor readings were averaged and used with the corresponding actual water content determined in the laboratory from intact soil core samples collected in three replicates from the close proximity of the sensors' zone of influence such that the center of the soil cores aligned with the center of the individual sensor. These samples were used to determine actual soil water content following the thermo-gravimetric method. These samples were also used to determine $\rho_{\mathrm{b}}$ and $\theta_{\mathrm{t}}$. Total porosity was also estimated from the following equation:

$$
\theta_{\mathrm{t}}=1-\frac{\rho_{\mathrm{b}}}{\rho_{\mathrm{s}}}
$$

where $\rho_{\mathrm{s}}$ is the particle density $\left(2.65 \mathrm{~g} \mathrm{~cm}^{-3}\right)$.

\subsection{Calibration Equations and Data Analyses}

Values of actual soil water content were plotted versus the respective readings (V) of the EC-20, ML2x, and SM200 to establish field calibration equations separately for the two depths $(20$ and $80 \mathrm{~cm})$ at each location. A factorial analysis of variance (ANOVA) was conducted to evaluate the effect of soil depths and locations on $\rho_{\mathrm{b}}, \theta_{\mathrm{t}}, \mathrm{CC}, \mathrm{EC}$, and $\mathrm{pH}$ using Statistix software package [24]. The coefficient of correlation $(r)$, which represents the degree of association between the calculated and the actual water content; the root mean square error (RMSE), which represents the accuracy of calibration equation to predict actual water content; and the mean bias error (MBE), which is an indicator of sensor's accuracy in form of the difference between means of the calculated and actual water contents, were used to evaluate the field and default calibration equations. The RMSE $\left(\mathrm{cm}^{3} \mathrm{~cm}^{-3}\right)$ and $\operatorname{MBE}\left(\mathrm{cm}^{3} \mathrm{~cm}^{-3}\right)$ were calculated as follows:

$$
\begin{aligned}
& \mathrm{RMSE}=\sqrt{\sum_{i=1}^{n}\left(\theta_{c i}-\theta_{a i}\right)^{2} / n} \\
& \mathrm{MBE}=\sum_{i=1}^{n}\left(\theta_{c i}-\theta_{a i}\right) / n
\end{aligned}
$$

where $\theta_{c i}$ and $\theta_{a i}$ are the calculated and actual water content in $\mathrm{cm}^{3} \mathrm{~cm}^{-3}$, respectively, and $n$ is the number of observations. Positive and negative values of MBE indicate over-estimation and 
under-estimation of the actual water content by the sensor, respectively. Larger $r$ and smaller RMSE and MBE represent high sensor accuracy and vice versa.

\section{Results and Discussion}

\subsection{Selected Soil Properties}

Across the six soil water content monitoring locations, the soils at $20 \mathrm{~cm}$ depth had larger CC than those at $80 \mathrm{~cm}$ depth (Table 3). Clay content at $20 \mathrm{~cm}$ depth ranged from 157 at location 6 to $610 \mathrm{~g} \mathrm{~kg}^{-1}$ at location 2; whereas, at $80 \mathrm{~cm}$ depth, the $\mathrm{CC}$ values ranged from 288 at locations 4 and 5 to $690 \mathrm{~g} \mathrm{~kg}^{-1}$ at location 2. Soil from both depths at locations 1 and 4 were clay loam. Locations 2 and 3 had clay soils at both depths; whereas, at location 5, loam and sandy loam soils existed at 20 and $80 \mathrm{~cm}$ soil depths, respectively. Soil from the $80 \mathrm{~cm}$ depth at location 6 was silty clay. Soils at location 6 had the smallest CC among the other sampling locations. Different NRCS soil series were found across the watershed. Location 1 had Molisol, location 2 had Inceptisol, and locations 3 through 5 had Ultisol. Andisols, formed by weathering of volcanic ash under well-drained conditions, dominated location 6; they are characterized by low bulk density (Table 3) and are favorable for keeping aerobic conditions [25].

Larger $\rho_{\mathrm{b}}$ was observed at $80 \mathrm{~cm}$ depth than at $20 \mathrm{~cm}$ depth across the six locations except at location 4 (Table 3). The opposite was expected for $\theta_{\mathrm{t}}$, given the inverse relationship between $\theta_{\mathrm{t}}$ and $\rho_{\mathrm{b}}$. Smaller $\rho_{\mathrm{b}}$ had resulted in larger $\theta_{\mathrm{t}}$ given their inverse relationship (Equation (1)). At the $20 \mathrm{~cm}$ depth, $\rho_{\mathrm{b}}$ ranged from 0.49 at locations 6 to $0.95 \mathrm{~g} \mathrm{~cm}^{-3}$ at location 4 ; however, at $80 \mathrm{~cm}$ depth, it ranged from 0.72 at location 6 to $1.27 \mathrm{~g} \mathrm{~cm}^{-3}$ at location 1 . At the $20 \mathrm{~cm}$ depth, $\theta_{\mathrm{t}}$ ranged from 0.66 at location 4 to $0.72 \mathrm{~cm}^{3} \mathrm{~cm}^{-3}$ at location 5 ; whereas, at $80 \mathrm{~cm}$ depth, it varied between 0.56 at location 1 and $0.67 \mathrm{~cm}^{3} \mathrm{~cm}^{-3}$ at locations 4 .

The values of EC at $20 \mathrm{~cm}$ soil depth were almost double of those at $80 \mathrm{~cm}$ soil depth at locations 1 through 3; whereas, at locations 4 and 5, the EC values at $20 \mathrm{~cm}$ soil depth were 1.5 and 1.2 times those at $80 \mathrm{~cm}$ soil depth, respectively (Table 3). At $20 \mathrm{~cm}$ soil depth, the EC ranged from 426 at location 3 to $2,016 \mu \mathrm{S} \mathrm{cm}^{-1}$ at location 1 ; whereas, at $80 \mathrm{~cm}$ soil depth, it ranged from 222 at location 3 to $1,270 \mu \mathrm{S} \mathrm{cm}^{-1}$ at location 4 . Decomposition of the organic matter from the tree litter might have resulted in the larger EC values of the soil samples of the $20 \mathrm{~cm}$ soil layer. Reduction in $\mathrm{pH}$ of the top soil layers at locations 1 through 3 might have also resulted from the decomposition of organic matter. The soils from the two depths of the six locations were acidic to neutral as their $\mathrm{pH}$ varied from 4.24 at $20 \mathrm{~cm}$ depth at location 2 to 5.81 at $20 \mathrm{~cm}$ depth at location 5.

ANOVA results showed a significant $(P<0.05)$ increase in $\rho_{\mathrm{b}}$ and EC values and a significant $(P<0.05)$ decrease in $\theta_{\mathrm{t}}$ with increase in soil depth (Table 4$)$. This may be due to compaction as a result of the overburden from the above soil load. Soil compaction enhanced $\rho_{\mathrm{b}}$ and thus reduced $\theta_{\mathrm{t}}$ as shown by Equation (1). There was no significant effect of soil depth on $\mathrm{CC}$ and soil $\mathrm{pH}$. Location had a significant $(P<0.05)$ effect on $\rho_{\mathrm{b}}, \theta_{\mathrm{t}}$, and EC and a highly significant $(P<0.01)$ effect on CC. 
Table 3. Measured soil bulk density $\left(\rho_{\mathrm{b}}\right)$, total porosity $\left(\theta_{\mathrm{t}}\right)$, electrical conductivity (EC) and $\mathrm{pH}$ of the soil samples collected from 20 and $80 \mathrm{~cm}$ depths at the six monitoring locations in the upper Mākaha Valley sub-watershed.

\begin{tabular}{cccccc}
\hline Location & $\begin{array}{c}\text { Depth } \\
(\mathbf{c m})\end{array}$ & $\begin{array}{c}\boldsymbol{\rho}_{\mathbf{b}} \mathbf{g} \\
\left(\mathbf{c m}^{-3}\right)\end{array}$ & $\begin{array}{c}\boldsymbol{\theta}_{\mathbf{t}} \mathbf{c m}^{\mathbf{3}} \\
\left(\mathbf{c m}^{-3}\right)\end{array}$ & $\begin{array}{c}\mathbf{E C} \\
\left(\mathbf{c m}^{\mathbf{3}} \mathbf{\mu} \mathbf{S}\right.\end{array}$ & $\mathbf{p H}^{\#}$ \\
\hline \multirow{2}{*}{1} & 20 & 0.93 & 0.69 & 2016 & 5.01 \\
& 80 & 1.27 & 0.56 & 840 & 5.52 \\
2 & 20 & 0.86 & 0.67 & 802 & 4.24 \\
& 80 & 1.06 & 0.60 & 480 & 4.29 \\
3 & 20 & 0.83 & 0.67 & 426 & 4.60 \\
& 80 & 0.97 & 0.58 & 222 & 4.69 \\
4 & 20 & 0.95 & 0.66 & 1888 & 5.65 \\
& 80 & 0.93 & 0.67 & 1270 & 4.91 \\
5 & 20 & 0.69 & 0.72 & 1220 & 5.81 \\
& 80 & 0.93 & 0.61 & 1024 & 4.89 \\
6 & 20 & 0.49 & 0.80 & 1189 & 4.88 \\
& 80 & 0.72 & 0.75 & 959 & 5.09 \\
\hline
\end{tabular}

${ }^{\#}$ Electrical conductivity and $\mathrm{pH}$ measurements were made on 1:2 soil:water solutions.

Table 4. Results of the factorial general analysis of variance for bulk density, porosity, and clay contents, electrical conductivity, and $\mathrm{pH}$ as a function of soil depths and locations.

\begin{tabular}{cccccl}
\hline Factors & Bulk Density & $\begin{array}{c}\text { Total } \\
\text { Porosity }\end{array}$ & $\begin{array}{c}\text { Clay } \\
\text { Contents }\end{array}$ & $\begin{array}{c}\text { Electrical } \\
\text { Conductivity }\end{array}$ & pH \\
\hline Depth & $0.0125^{*}$ & $0.0153^{*}$ & $\mathrm{NS}$ & $0.0336^{*}$ & $\mathrm{NS}$ \\
Location & $0.0220^{*}$ & $0.0463^{*}$ & $0.0026^{* *}$ & $0.0355^{*}$ & $\mathrm{NS}$ \\
Interaction & $\mathrm{NS}$ & $\mathrm{NS}$ & $\mathrm{NS}$ & $\mathrm{NS}$ & $\mathrm{NS}$ \\
\hline
\end{tabular}

*: significant; **: highly significant; NS: not significant.

\subsection{Spatial Variability of Bulk Density and Total Porosity}

In general, major soil properties including $\rho_{\mathrm{b}}$ and $\theta_{\mathrm{t}}$ are consistent for a given soil type, series or order. Variations in $\rho_{\mathrm{b}}$ and $\theta_{\mathrm{t}}$ are due to many factors such as high organic matter, CC or both. Most of the shrink-swell clays exhibited variability in $\rho_{\mathrm{b}}$ and $\theta_{\mathrm{t}}$. The shrink-swell behavior of the soils at locations 1 through 5 was confirmed from the good agreement between the actual $\theta_{\mathrm{t}}$ and those calculated from Equation 1 (Figure 2). Small $\mathrm{CC}$ at location 6 suppressed soil shrinking and swelling at this location resulting in a weak correlation $(r<0.4)$ between the actual and calculated $\theta_{\mathrm{t}}$.

Pearson's correlation test was conducted to correlate $\rho_{\mathrm{b}}$ and $\theta_{\mathrm{t}}$ at 20 and $80 \mathrm{~cm}$ depths. Overall, there was a non-significant inverse relationship between $\rho_{\mathrm{b}}$ and $\theta_{\mathrm{t}}$ except at $20 \mathrm{~cm}$ depth where a stronger $(r=-0.93)$ inverse significant $(P<0.05)$ relationship existed. The strongest $(r=0.95)$ significant $(P<0.05)$ relationship between $\rho_{\mathrm{b}}$ at 20 and $80 \mathrm{~cm}$ depths reflected the increasing trend of $\rho_{\mathrm{b}}$ with soil depth at all experimental locations. 
Figure 2. Correlation between the actual total porosity at the two depths $(20$ and $80 \mathrm{~cm})$ and that estimated from the relationship $\theta_{\mathrm{t}}=1-\rho_{\mathrm{b}} / \rho_{\mathrm{s}}$, where $\theta_{\mathrm{t}}$ is total porosity, $\rho_{\mathrm{b}}$ is bulk density, and $\rho_{\mathrm{s}}$ is the particle density $\left(2.65 \mathrm{~g} \mathrm{~cm}^{-3}\right)$.

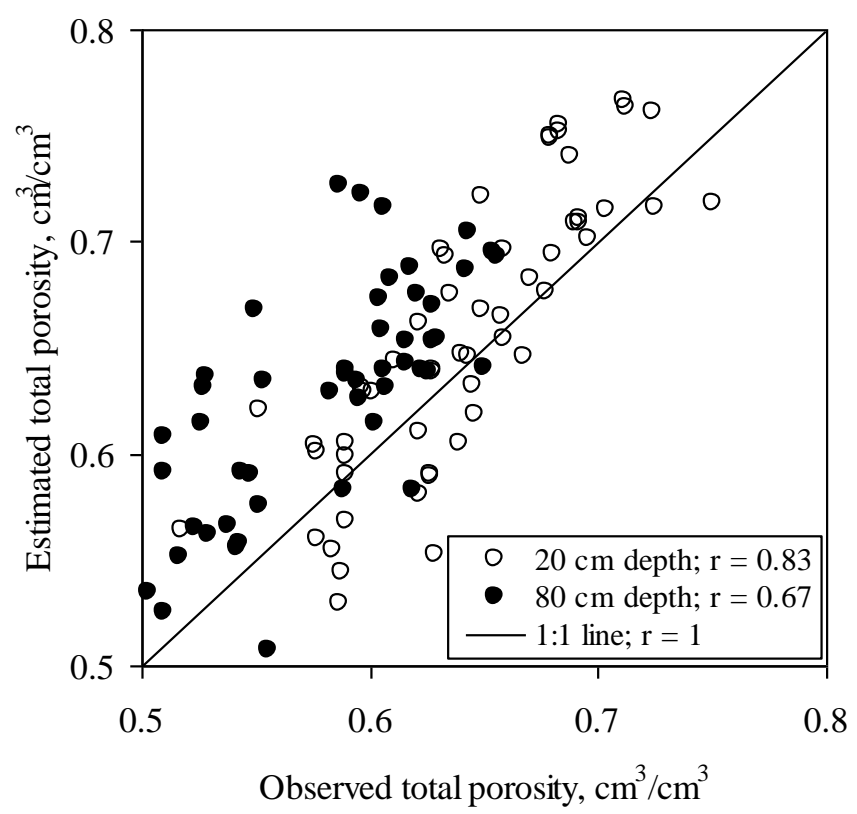

\subsection{Soil Water Content Dynamics due to Spatial Variability of Bulk Density and Total Porosity}

There was a linear increase in $\rho_{\mathrm{b}}$ and a linear decrease in $\theta_{\mathrm{t}}$ with increase in soil water content at all depths and locations (Figure 3). Slopes of the $\rho_{\mathrm{b}}$-water content and $\theta_{\mathrm{t}}$-water content models for the two depths and six locations were non-uniform reflecting a great spatial variability in these properties. This was an indicator of great soil water content dynamics due to shrinking and swelling-induced changes in $\rho_{\mathrm{b}}$ and $\theta_{\mathrm{t}}$. Such behavior of water content dynamics emphasized the need for site-specific calibration equations for soil water content sensors. There were weak $\theta_{\mathrm{t}}$-water content relationships $(r=7 \mathrm{E}-04,0.02)$ at location 6 [Figures 3(r,x)] partially due to high ash and organic matter contents and partially due to poor structure of highly weathered soil (personal observations). Volcanic ash soils are classified as an Andisol with low densities and assumption of $\rho_{\mathrm{s}}=2.65 \mathrm{~g} \mathrm{~cm}^{-3}$ may not be valid for these soils [25]. Moreover, Andisol usually have peculiar permittivity relations due to high surface area and low densities [26-30]. Our results showed that variations in $\rho_{\mathrm{b}}$ can affect soil water content estimation of high CC soils due to their shrink-swell behavior. Fares et al. [31] and Polyakov et al. [32] reported similar results for a sandy clay loam soil and for a weathered clay loam soil, respectively. Yule [33] and Smith [34] have reported errors in volumetric water content calculation made from $\rho_{\mathrm{b}}$ information when the $\rho_{\mathrm{b}}$ was not determined at the right moisture content. 
Figure 3. Effect of spatial variability of soil bulk density (figures on left) and actual total porosity (figures on right) on field measured soil water content.

Bulk Density
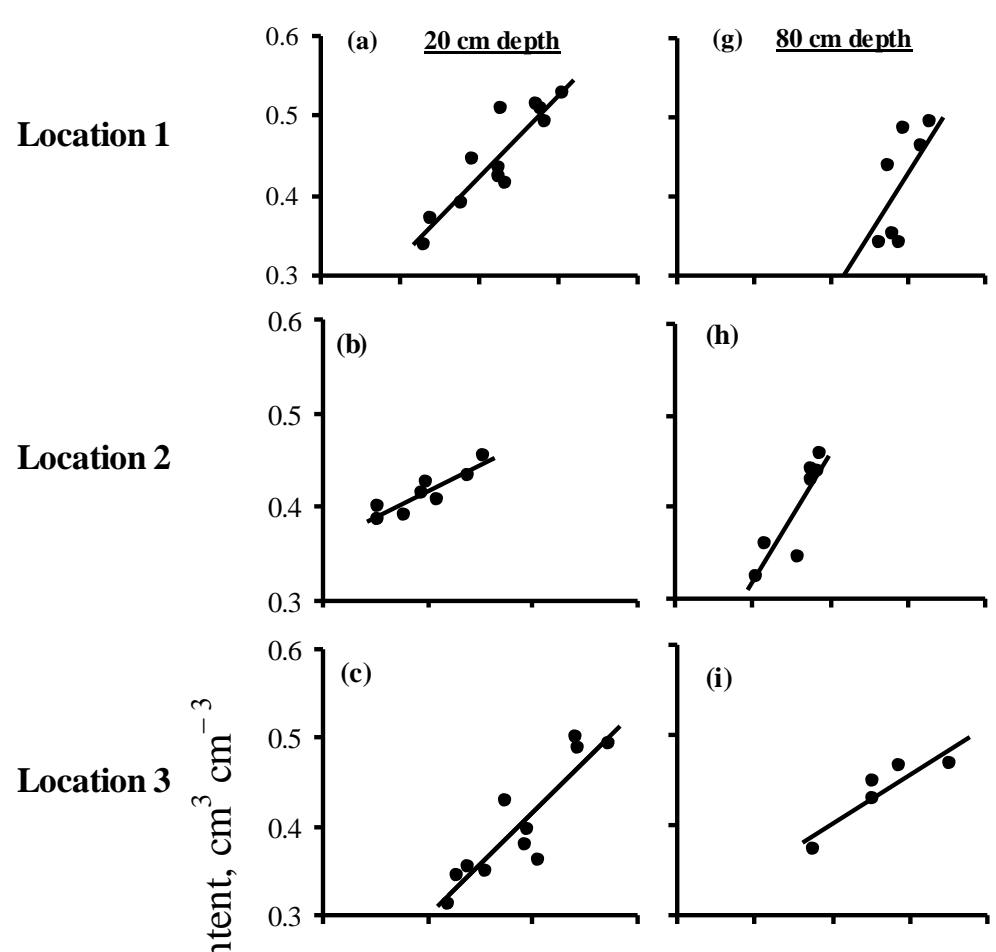

Location 4

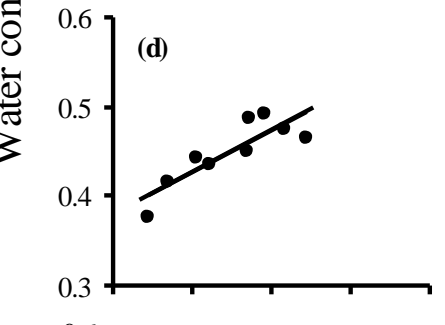

Location 5

Location 6
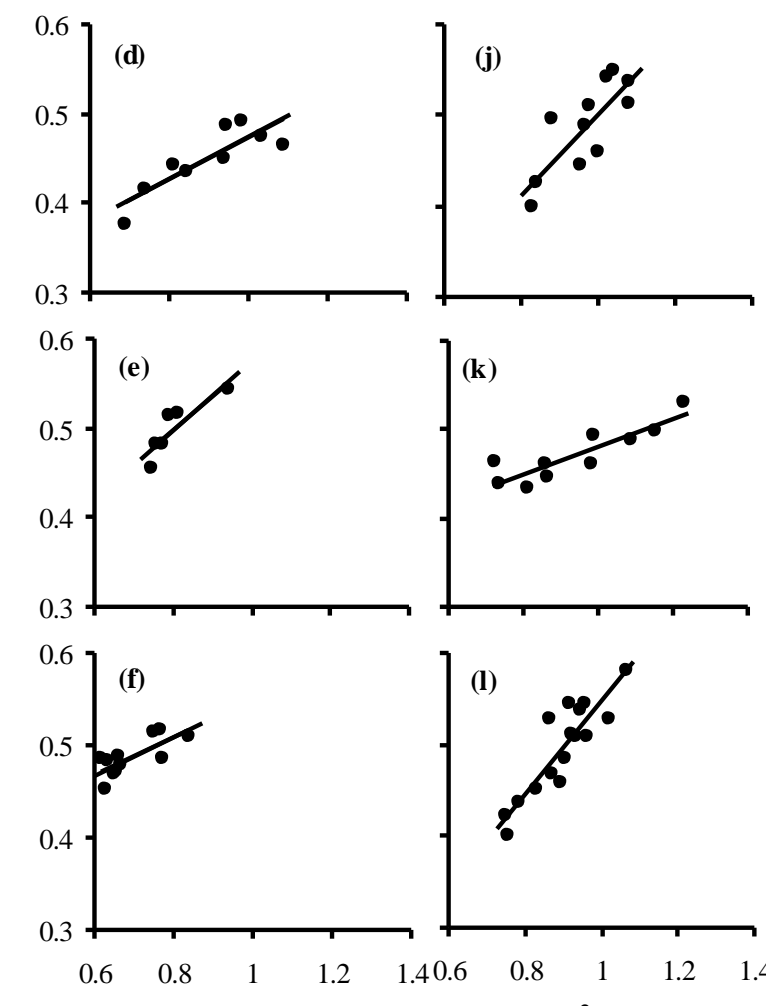

Bulk density, $\mathrm{g} \mathrm{cm}^{-3}$
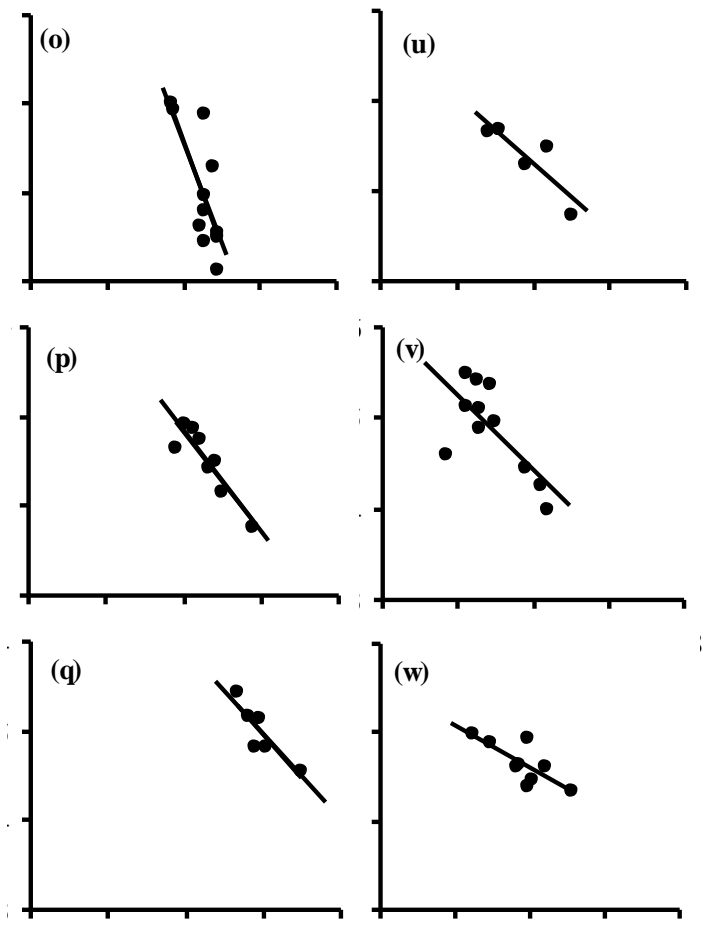

Porosity
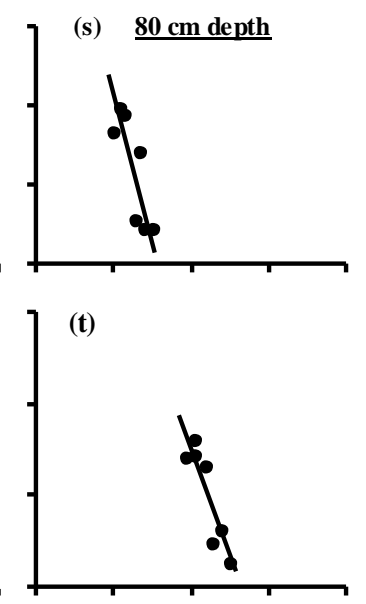

(u)
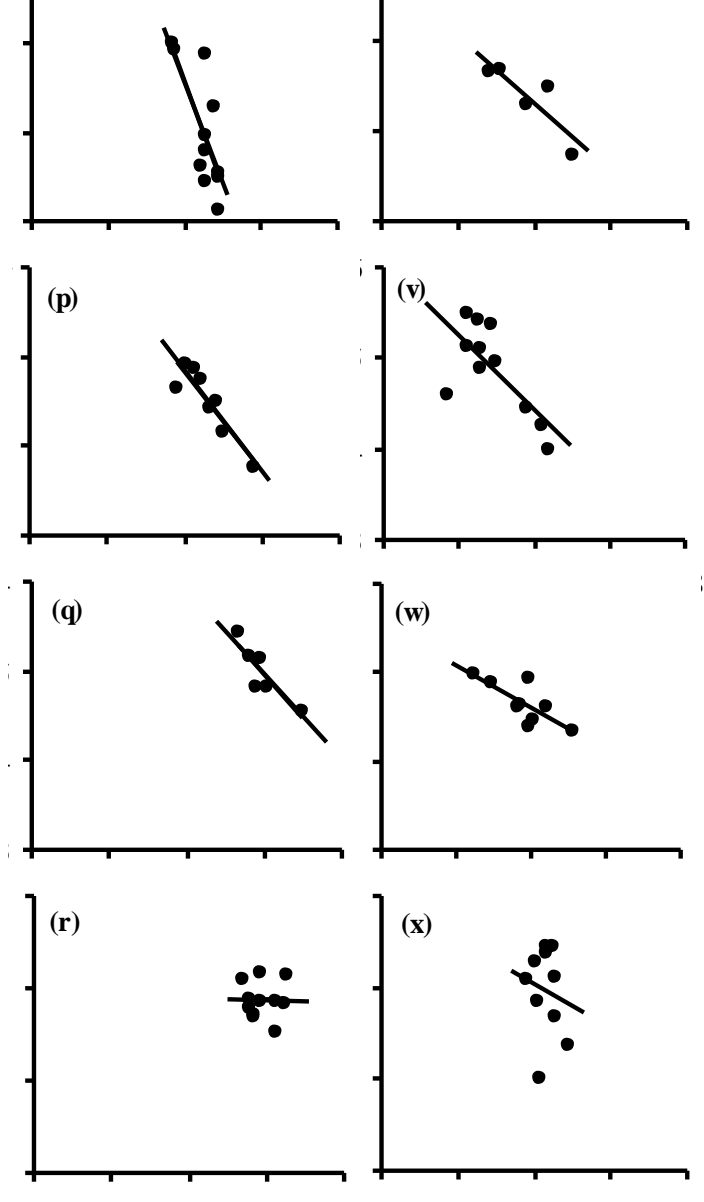

(x)

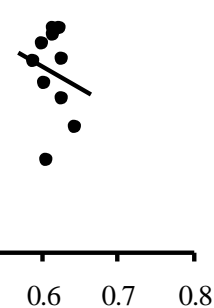

Total porosity, $\mathrm{cm}^{3} \mathrm{~cm}^{-3}$ 


\subsection{Field Calibration of Sensors}

Since soil depths and locations had significant effect on $\rho_{\mathrm{b}}, \theta_{\mathrm{t}}, \mathrm{CC}$, and EC (Table 4) in addition to the significant effect of $\rho_{\mathrm{b}}$ and $\theta_{\mathrm{t}}$ on soil water content dynamics (Figure 3), field calibration equations for each sensor were established for each depth and location (Table 5). These site-specific field calibration equations of the EC-20, ML2x, and SM200 accurately predicted the actual water content ( $r>0.88$; RMSE 0.011 to $\left.0.054 \mathrm{~cm}^{3} \mathrm{~cm}^{-3}\right)$, compared with their respective default equations $(r>0.86$; RMSE 0.026 to $0.247 \mathrm{~cm}^{3} \mathrm{~cm}^{-3}$ ). The values of RMSE and MBE of the actual water content and the calculated water content using default equations are inside the parentheses in Table 5. The values of MBE for the site-specific field calibration equations were smaller than those of their corresponding default equations indicating that the site-specific field calibration equations had significantly improved the accuracy of soil water content measurements of these sensors. On the other hand, the default calibration equations substantially under-estimated (larger absolute negative value of MBE) the actual water content compared with their corresponding site-specific field calibration equations (smaller MBE).

The watershed-scale field calibration equations (one equation of each sensor for all depths and locations) of the three sensors seem to substantially $(P<0.001)$ improve the accuracy of the tested sensors (Table 6). Estimation of actual water content using these new equations resulted in smaller RMSE and MBE as compared with their corresponding default equations. The ML2x exhibited the highest improvement in its accuracy with the use of the new calibration equation $\left(r=0.81\right.$; RMSE $\left.0.038 \mathrm{~cm}^{3} \mathrm{~cm}^{-3}\right)$ over its default equation $\left(r=0.79\right.$; RMSE $\left.0.189 \mathrm{~cm}^{3} \mathrm{~cm}^{-3}\right)$.

Similar improvement in the accuracy of the SM200 was achieved with the watershed-scale field calibration equations (RMSE $0.042 \mathrm{~cm}^{3} \mathrm{~cm}^{-3}$ ) compared with the default equation (RMSE $0.155 \mathrm{~cm}^{3} \mathrm{~cm}^{-3}$ ). There was a better agreement between actual water content and that measured by the SM200 watershed-scale field calibration equation $\left(\mathrm{MBE}-0.001 \mathrm{~cm}^{3} \mathrm{~cm}^{-3}\right)$ than between actual water content and that determined by the default equation (MBE $-0.126 \mathrm{~cm}^{3} \mathrm{~cm}^{-3}$ ). EC-20 showed the least improvement in its accuracy among the tested sensors with the use of watershed-scale field calibration equation (RMSE $0.054 \mathrm{~cm}^{3} \mathrm{~cm}^{-3}$; MBE $-0.034 \mathrm{~cm}^{3} \mathrm{~cm}^{-3}$ ) compared to that of its default equation (RMSE $0.068 \mathrm{~cm}^{3} \mathrm{~cm}^{-3}$; MBE $-0.014 \mathrm{~cm}^{3} \mathrm{~cm}^{-3}$ ).

The performance of the default and watershed site-specific calibration equations in tracking the actual water content is detailed in Figure 4. There was a minimal difference between the performance of the field and the default (MBE $-0.034 \mathrm{~cm}^{3} \mathrm{~cm}^{-3} v s .-0.014 \mathrm{~cm}^{3} \mathrm{~cm}^{-3}$ ) equations of EC-20 (Figure 4(a); Table 6).

\section{Conclusions}

The effect of spatial variability of $\rho_{\mathrm{b}}, \theta_{\mathrm{t}}, \mathrm{CC}$, and EC on the performance of EC-20, ML2x, and SM200 sensors installed at 20 and $80 \mathrm{~cm}$ depths on six locations across the forested upper Mākaha Valley watershed in O'ahu (Hawai'I, USA) was studied. The studied soil properties significantly varied as a function of the water content monitoring depths and locations. Field calibration equations for the three tested sensors improved their performance for accurate measurement of actual soil water content. 
Table 5. Equation parameters and statistical indices for the laboratory calibration equations for EC-20, ML2x, and SM200. The values of root mean square error (RMSE) and mean bias error (MBE) from the comparison of actual water content with that calculated from the default sensor equations in parentheses.

\begin{tabular}{|c|c|c|c|c|c|c|c|c|}
\hline Location & Depth & Sensor & $a^{\mathrm{Tl}} \times 10^{-2}$ & $b^{\S} \times 10^{-2}$ & $r$ & RMSE $\div 10^{2}, \mathrm{~cm}^{3} \mathrm{~cm}^{-3}$ & MBE $\div 10^{2}, \mathrm{~cm}^{3} \mathrm{~cm}^{-3}$ & $n$ \\
\hline \multirow[t]{6}{*}{1} & 20 & EC-20 & 0.04 & -1.71 & $0.954(0.945)$ & $3.63(12.0)$ & $2.82(10.0)$ & 16 \\
\hline & & ML2x & 48.68 & 20.31 & $0.917(0.919)$ & $3.00(24.7)$ & $-0.15(-24.5)$ & 16 \\
\hline & & SM200 & 30.10 & 29.85 & $0.968(0.974)$ & $3.73(14.9)$ & $0.00(-13.3)$ & 16 \\
\hline & 80 & EC-20 & 0.04 & -0.20 & $0.916(0.917)$ & $3.87(7.31)$ & $2.81(4.45)$ & 12 \\
\hline & & ML2x & 47.08 & 17.59 & $0.913(0.914)$ & $2.67(21.3)$ & $0.00(-21.1)$ & 12 \\
\hline & & SM200 & 24.97 & 28.25 & $0.911(0.903)$ & $2.70(11.5)$ & $-0.00(-8.63)$ & 12 \\
\hline \multirow[t]{6}{*}{2} & 20 & EC-20 & 0.03 & 11.51 & $0.917(0.917)$ & $1.79(7.19)$ & $-0.33(-4.65)$ & 16 \\
\hline & & ML2x & 31.74 & 24.28 & $0.944(0.937)$ & $1.45(20.7)$ & $-0.03(-20.5)$ & 16 \\
\hline & & SM200 & 27.05 & 32.38 & $0.930(0.939)$ & $1.62(19.9)$ & $-0.00(-19.0)$ & 16 \\
\hline & 80 & EC-20 & 0.05 & -7.17 & $0.929(0.928)$ & $3.60(2.61)$ & $3.19(-0.39)$ & 12 \\
\hline & & ML2x & 26.0 & 25.01 & $0.929(0.926)$ & $1.63(18.1)$ & $-0.00(-17.7)$ & 12 \\
\hline & & SM200 & 18.39 & 31.25 & $0.960(0.957)$ & $1.59(13.4)$ & $1.00(-10.3)$ & 12 \\
\hline \multirow[t]{6}{*}{3} & 20 & EC-20 & 0.04 & -2.30 & $0.933(0.933)$ & $5.40(6.04)$ & $-4.75(-2.45)$ & 16 \\
\hline & & ML2x & 55.24 & 13.01 & $0.921(0.919)$ & $2.79(21.3)$ & $-0.08(-21.0)$ & 16 \\
\hline & & SM200 & 27.05 & 32.38 & $0.921(0.922)$ & $2.80(12.7)$ & $-0.00(-12.3)$ & 16 \\
\hline & 80 & EC-20 & 0.04 & 0.12 & $0.935(0.935)$ & $1.66(5.10)$ & $1.26(4.46)$ & 10 \\
\hline & & ML2x & 19.49 & 28.66 & $0.920(0.925)$ & $1.18(13.8)$ & $-0.00(-13.0)$ & 10 \\
\hline & & SM200 & 42.16 & 24.84 & $0.891(0.891)$ & $1.36(9.28)$ & $0.00(-0.14)$ & 10 \\
\hline \multirow[t]{6}{*}{4} & 20 & EC-20 & 0.04 & 15.1 & $0.909(0.909)$ & $2.14(6.13)$ & $1.18(-2.16)$ & 18 \\
\hline & & ML2x & 24.25 & 32.0 & $0.884(0.877)$ & $1.99(23.8)$ & $0.27(-23.4)$ & 18 \\
\hline & & SM200 & 17.64 & 38.07 & $0.878(0.890)$ & $2.04(18.4)$ & $-0.00(-16.5)$ & 18 \\
\hline & 80 & EC-20 & 0.04 & -0.12 & $0.917(0.917)$ & $1.61(5.78)$ & $-16.0(-4.08)$ & 14 \\
\hline & & ML2x & 38.53 & 21.79 & $0.883(0.864)$ & $0.75(19.6)$ & $-0.00(-19.4)$ & 14 \\
\hline & & SM200 & 16.81 & 40.36 & $0.917(0.912)$ & $3.50(16.5)$ & $-0.95(-13.8)$ & 14 \\
\hline
\end{tabular}


Table 5. Cont.

\begin{tabular}{|c|c|c|c|c|c|c|c|c|}
\hline Location & Depth & Sensor & $a^{\mathrm{II}} \times 10^{-2}$ & $b^{\S} \times 10^{-2}$ & $r$ & $\mathrm{RMSE} \div 10^{2}, \mathrm{~cm}^{3} \mathrm{~cm}^{-3}$ & $\mathrm{MBE} \div 10^{2}, \mathrm{~cm}^{3} \mathrm{~cm}^{-3}$ & $n$ \\
\hline \multirow[t]{6}{*}{5} & 20 & EC-20 & 0.03 & 15.02 & $0.908(0.908)$ & $2.21(6.83)$ & $-0.53(-2.62)$ & 12 \\
\hline & & $\operatorname{ML} 2 \mathrm{x}$ & 60.96 & -1.05 & $0.897(0.888)$ & $3.08(13.1)$ & $2.10(-12.9)$ & 12 \\
\hline & & SM200 & - & - & - & - & - & - \\
\hline & 80 & EC-20 & 0.04 & -4.12 & $0.911(0.911)$ & $10.7(6.18)$ & $-10.6(-5.38)$ & 16 \\
\hline & & ML2x & 33.44 & 18.39 & $0.903(0.910)$ & $1.82(8.91)$ & $0.17(-7.73)$ & 16 \\
\hline & & SM200 & - & - & - & - & - & - \\
\hline \multirow[t]{6}{*}{6} & 20 & EC-20 & 0.04 & -0.20 & $0.942(0.942)$ & $12.3(6.83)$ & $-12.2(-5.73)$ & 18 \\
\hline & & $\operatorname{ML} 2 x$ & 31.09 & 20.04 & $0.906(0.886)$ & $0.95(9.02)$ & $0.00(-8.68)$ & 12 \\
\hline & & SM200 & - & - & - & - & - & - \\
\hline & 80 & EC-20 & 0.06 & -9.29 & $0.961(0.961)$ & $5.26(4.93)$ & $5.10(-4.66)$ & 16 \\
\hline & & $\operatorname{ML} 2 \mathrm{x}$ & 26.51 & 30.51 & $0.943(0.953)$ & $1.08(16.5)$ & $-0.00(-15.9)$ & 7 \\
\hline & & SM200 & - & - & - & - & - & - \\
\hline
\end{tabular}

Table 6. Regression parameters of watershed-specific field calibration equations and accuracy indicators (RMSE; root mean squared error and MBE; mean bias error) of field and default equations.

\begin{tabular}{|c|c|c|c|c|c|c|c|c|}
\hline Sensor & $N$ & Calibration & $a^{\text {II }}$ & $b^{\S}$ & $\mathbf{P}$ & $r$ & RMSE $\div 10^{2}, \mathrm{~cm}^{3} \mathrm{~cm}^{-3}$ & MBE, $\div 10^{2}, \mathrm{~cm}^{3} \mathrm{~cm}^{-3}$ \\
\hline \multirow{2}{*}{ EC-20 } & \multirow{2}{*}{176} & Field & 0.3 & 0.0969 & $4.24 \mathrm{E}-33$ & 0.75 & 5.41 & -3.36 \\
\hline & & Default & 0.695 & -0.29 & $4.24 \mathrm{E}-33$ & 0.75 & 6.84 & -1.37 \\
\hline \multirow{2}{*}{ ML2x } & \multirow{2}{*}{160} & Field & 0.2592 & 0.2768 & $1.41 \mathrm{E}-38$ & 0.81 & 3.79 & 0.002 \\
\hline & & Default & $\#$ & $\#$ & $1.34 \mathrm{E}-35$ & 0.79 & 18.9 & -17.7 \\
\hline \multirow{2}{*}{ SM200 } & \multirow{2}{*}{113} & Field & 0.2109 & 0.3334 & $2.06 \mathrm{E}-22$ & 0.75 & 4.22 & -0.103 \\
\hline & & Default & \# & $\#$ & $4.46 \mathrm{E}-23$ & 0.76 & 15.5 & -12.6 \\
\hline
\end{tabular}

${ }^{\mathrm{II}}$ slope; ${ }^{\S} y$ intercept; \#: Parameters are given in Table 1 . 
Figure 4. Field measured actual volumetric water content versus sensors' readings plotted with default and site-specific field calibration models for (A) EC-20; (B) ML2x; and (C) SM200.
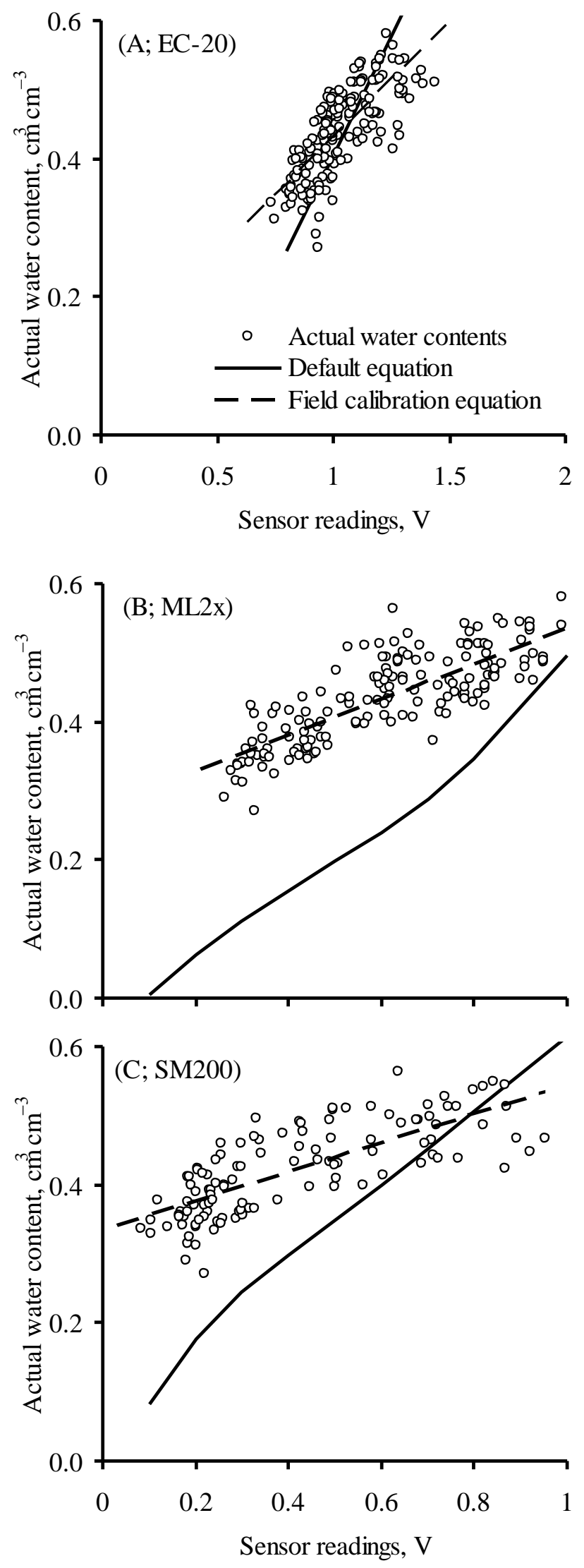
The default equations of the ML2x and SM200 showed substantial under-estimations of actual water content; whereas, the field calibration equations of these sensors substantially improved their accuracy of measuring actual water content. The EC-20 default equation performed better than the default equations of the other two sensors. Moreover, there was no significant difference in the performance of the default and the field calibration equations of EC-20. EC-20 had the least improvement in its accuracy with the use of field calibration equation as compared with the other two sensors. Overall, the field calibration equations were more accurate in estimating soil water content (higher P, $r$ and lower RMSE, MBE) than their corresponding default equations. The tested sensors need site-specific calibrations for accurate measurement of actual water content of these highly weathered tropical soils. The field calibration equations can mitigate the effects of varying soil properties and improve the accuracy of the tested sensors.

\section{Acknowledgements}

This project was supported by two grants from the US Department of Agriculture: (1) Cooperative State Research, Education and Extension Service grant number 2004-34135-15058, (2) McIntire-Stennis formula grant number 2006-34135-17690. The authors wish to thank the Honolulu Board of Water Supply for cooperation, and Amjad Ahmad, Nghia Dai Tran, Mohammad Safeeq, Alan Mair and other members of the Watershed Hydrology Laboratory for their help during the field work.

\section{References}

1. Hawley, M.E.; Jackson, T.J.; McCuen, R.H. Surface soil moisture variation on small agricultural watersheds. J. Hydrol. 1983, 62, 179-200.

2. Reynolds, S.G. The gravimetric method of soil moisture determination. III. An examination of factors influencing soil moisture variability. J. Hydrol. 1970, 11, 288-300.

3. Western, A.W.; Blöschl, G. On the spatial scaling of soil moisture. J. Hydrol. 1999, 217, 203-224.

4. Gómez-Plaza, A.; Martínez-Mena, M.; Albaladejo, J.; Castillo, V.M. Factors regulating spatial distribution of soil water content in small semiarid catchments. J. Hydrol. 2001, 253, 211-226.

5. Hu, W.; Shao, M.A.; Wang, Q.J.; Reichardt, K. Soil water content temporal-spatial variability of the surface layer of a loess plateau hillside in china. Sci. Agric. 2008, 65, 277-289.

6. Paige, G.B.; Keefer, T.O. Comparison of field performance of multiple soil moisture sensors in a semi-arid rangeland. J. Am. Water Resour. Assoc. 2008, 44, 121-135.

7. Gardner, W.H. Water content. In Methods of Soil Analysis, Part 1. Physical and Mineralogical Methods; SSSA Book Ser. 5; Klute, A., Ed.; SSSA: Madison, WI, USA, 1986; pp. 493-544.

8. Fares, A.; Polyakov, V. Advances in crop water management using capacitive water sensors. Adv. Agron. 2006, 90, 43-77.

9. Robinson, D.A.; Campbell, C.S.; Hopmans, J.W.; Hornbuckle, B.K.; Jones, S.B.; Knight, R.; Ogden, F.; Selker, J.; Wendroth, O. Soil moisture measurement for ecological and hydrological watershed-scale observatories: A review. Vadose Zone J. 2008, 7, 358-389.

10. Decagon Devices, Inc. $\mathrm{ECH}_{2} \mathrm{O}$ Utility Mobile for Windows Handheld PCs Operator's Manual, 2002. Available online: http://www.decagon.com/literature/manuals/Ech2oUtilityMobile Manual.pdf/ (accessed on 12 March 2009). 
11. Dynamax Inc. ThetaProbe Type ML2x. 2009. Available online: ftp://ftp.dynamax.com/ DynamaxPDF/irrigation-controls/ML2x.pdf (accessed on 12 March 2009).

12. Foley, J.L.; Harris, E. Field calibration of ThetaProbe (ML2x) and ECHO probe (EC-20) soil water sensors in a Black Vertosol. Aust. J. Soil Res. 2007, 45, 233-236.

13. Fares, A.; Hamdhani, H.; Jenkins, D.M. Temperature-dependent scaled frequency: Improved accuracy of multisensor capacitance probes. Soil Sci. Soc. Am. J. 2007, 71, 894-900.

14. Czarnomski, N.M.; Moore, G.W.; Pypker, T.G.; Licata, J.; Bond, B.J. Precision and accuracy of three alternative instruments for measuring soil water content in two forest soils of the Pacific Northwest. Can. J. For. Res. 2005, 35, 1867-1876.

15. Logsdon, S.D.; Hornbuckle, B. Soil moisture probes for dispersive soils. In Proceedings of TDR 2006: Third International Symposium and Workshop on Time Domain Reflectometry for Innovative Soils Applications, Purdue University: West Lafayette, IN, USA, 2006. Available online: https://engineering.purdue.edu/TDR/Papers/13_Paper.pdf (accessed on 12 March 2009).

16. Hu, Y.; Vu, H.; Hubble, D. Water content measurement in highly plastic clay using dielectric based probes. Can. Geotech. J. 2010, 41, 997-1010.

17. Fares, A. Determining the Impacts of Water Pumping and Alien Species Invasion on Stream Flow for a Sustainable Water Resource Management in Mākaha Valley; Project report submitted to the Board of Water Supply; University of Hawaii: Honolulu, HI, USA, September 2007.

18. Whalley, W.R. Considerations on the use of time-domain reflectometry (TDR) for measuring soil moisture content. J. Soil Sci. 1993, 44, 1-9.

19. White, I.K.; Zegelin, J.H.; Topp, G.C. Comments on 'Considerations on the use of time-domain reflectometry (TDR) for measuring soil water content' by W.R. Whalley. J. Soil Sci. 1994. 45, 503-508.

20. Foote, D.E.; Hill, E.L.; Nakamura, S.; Stephens, F. Soil Survey of the Islands of Kauai, Oahu, Maui, Molokai, and Lanai, State of Hawaii; United States Department of Agriculture, United States Printing Office: Washington, DC, USA, 1972.

21. Grossman, R.B.; Reinsch, T.G. Bulk density and linear extensibility. In Methods of Soil Analysis, Part 4; SSSA Book Ser. 5; Dane, J.H., Topp, G.C., Eds.; SSSA: Madison, WI, USA, 2002; pp. 201-254.

22. Flint, L.E.; Flint, A.L. Porosity. In Methods of Soil Analysis, Part 4; SSSA Book Ser. 5; Dane, J.H., Topp, G.C., Eds.; SSSA: Madison, WI, USA, 2002; pp. 241-254.

23. Gee, G.W.; Or, D. Particle-size analysis. In Methods of Soil Analysis, Part 4; SSSA Book Ser. 5; Dane, J.H., Topp, G.C., Eds.; SSSA: Madison, WI, USA, 2002; pp. 255-293.

24. Analytical Software. User's Manual: STATISTIX8; Analytical Software: Tallahassee, FL, USA, 2003.

25. Chu. H.Y.; Hosen, Y.; Yagi, K.; Okada, K.; Ito, O. Soil microbial biomass and activities in a Japanese. Andisol as affected by controlled release and application depth of urea. Biol. Fertil. Soils 2005, 42, 89-96.

26. Weitz, A.M.; Grauel, W.T.; Keller, M.; Veldkamp, E. Calibration of time domain reflectometry technique using undisturbed soil samples from humid tropical soils of volcanic origin. Water Resour. Res. 1997, 33, 1241-1249. 
27. Tomer, M.D.; Clothier, B.E.; Vogeler, I.; Green, S. A dielectric-Water content relationship for sandy volcanic soils in New Zealand. Soil Sci. Soc. Am. J. 1999, 63, 777-781.

28. Veldkamp, E.; O’Brien, J.J. Calibration of a frequency domain reflectoetry sensor for humid tropical soils of volcanic origin. Soil Sci. Soc. Am. J. 2000, 64, 1549-1553.

29. Miyamoto, T.; Annaka, T.; Chikushi, J. Soil aggregate structure effects on dielectric permittivity of an Andisol measured by time domain reflectometry. Vadose Zone J. 2003, 2, 90-97.

30. Regalado, C.M.; Ritter, A.; Rodrguez-Gonzalez, R.M. Performance of the commercial WET capacitance sensor as compared with Time Domain Reflectometry in volcanic soils. Vadoze Zone J. 2007, 6, 244-254.

31. Fares, A.; Buss, P.; Dalton, M.; El-Kadi, A.I.; Parsons, L.R. Dual field calibration of capacitance and neutron sensors in a shrinking-swelling clay soil. Vadose Zone J. 2004, 3, 1390-1399.

32. Polyakov, V.; Fares, A.; Ryder, M.H. Calibration of capacitance system for measuring water content of tropical soil. Vadose Zone J. 2005, 4, 1004-1010.

33. Yule, D.F. Volumetric calculations in cracking clay soils. In The Properties and Utilization of Cracking Clay Soils; Reviews in Rural Science. No. 5; McGarity, J.W., Hoult, E.H., So, H.B., Eds.; University of New England: Armidale, NSW, Australia, 1984; pp. 136-140.

34. Smith, G.D. Soil constituent and prehistory effects on aggregates porosity in cracking clays. In The Properties and Utilization of Cracking Clay Soils; Reviews in Rural Science, No. 5; McGarity, J.W., Hoult, E.H., So, H.B., Eds.; University of New England: Armidale, NSW, Australia, 1984; pp. 109-115.

(C) 2011 by the authors; licensee MDPI, Basel, Switzerland. This article is an open access article distributed under the terms and conditions of the Creative Commons Attribution license (http://creativecommons.org/licenses/by/3.0/). 